\title{
The Role of Financial Literacy, Gender, Education, and Ethnicity towards Investment Decisions
}

\author{
Wirawan ED Radianto1, Yosefa Lianoto', Tommy Christian Efrata ${ }^{2}$, and Liliana \\ Dewi $^{2}$ \\ ${ }^{1}$ Department of Accounting, Universitas Ciputra Surabaya, Indonesia \\ ${ }^{2}$ Department of Management, Universitas Ciputra Surabaya, Indonesia
}

Corresponding Author:

Wirawan ED Radianto

email@gmail.com

Received: 30 December 2019

Accepted: 29 January 2020

Published: 6 February 2020

Publishing services provided by

Knowledge E

(c) Wirawan ED Radianto

et al. This article is distributed under the terms of the Creative Commons Attribution License, which permits unrestricted use and redistribution provided that the original author and source are credited.

Selection and Peer-review under the responsibility of the 6 th ICOEN 2019 Conference Committee.

\begin{abstract}
The awareness and desire to allocate funds to meet future needs have caused many employees to start investing. The purpose of this study is to investigate the influence of the level of financial literacy and demographic factors on employee investment decisions. This study uses multiple linear regression analysis models to analyze data. The population in this study is employees with the criteria of having an investment instrument, either real or financial asset investments. The results of this study indicate that only the level of financial literacy partially influences investment decisions while gender, education, and ethnicity do not affect employee investment decisions.
\end{abstract}

Keywords: Financial Literacy, Gender, Education, Ethnicity, Investment Decisions

\section{Introduction}

The rapid economic development and increasingly consumptive lifestyles encourage people to obtain alternative income and to learn allocating funds that are owned as early as possible to manage finance in the present for future benefits [1--3]. One of the methods is by investing. This investment activity is important for a country as a driver for capital growth, the country's economic development, and the creation of freedom investment concepts $[4,5]$.

When investing, an adequate level of financial literacy is needed so that individual financial decisions have a clear, precise direction and can deliver the desired results [6]. In addition to financial literacy factors, investor demographic characteristics can also influence investors in determining the type of investment [7]. The studies conducted by Pak \& Mahmood [8] and Chavali \& Mohanraj [9] show that gender significantly affects individual investment decisions.

Another factor that can influence investment decisions according to Pratiwi \& Prijati [7] is education. In general, people with high levels of education understand well how to 
make decisions to invest in financial management. While another factor that influence the choice of investment types is ethnicity. Perry \& Morris [10] said that there is an ethnic influence on one's financial behavior. Albaity \& Rahman's research [11] stated that there are characteristic differences between Malaysian Malays and Chinese Malays in selecting risky investments. This shows that ethnicity also influences investor behavior in making investment decisions. Based on the various descriptions above, the purpose of this study is to examine the influence of financial literacy level on employee investment decisions, gender influence on employee investment decisions, educational influence on employee investment decisions, and ethnic influence on employee investment decisions.

Yushita [12] defined financial literacy as a number of financial abilities and knowledge a person has to have in order to be able to manage a number of funds aimed at improving living standards and achieving prosperity. Financial literacy is also interpreted as the ability of individuals to make decisions related to their personal financial arrangements [13]. OJK defined financial literacy as a series of knowledge, beliefs, and skills that influence individual attitudes and behavior in improving the quality of decision-making related to financial management in order to achieve prosperity.

Gender is a concept that distinguishes how a man and a woman behaves. Research conducted by Pratiwi [7] stated that men have a tolerance to higher risks than women regarding investment decisions taken. In the study of Chavali \& Mohanraj [9] and Pak $\&$ Mahmood [8], gender was also shown to influence individual investment decisions.

Education is a process of changing attitudes and behavior of a person or a group of people through various efforts, teaching and training processes, and ways and acts of educating. Education is defined as the level of mastery of the knowledge possessed by a person and manifested through his ability to understand things well [14]. Formal education is a structured and tiered educational path consisting of basic education, secondary education, and higher education. Higher education includes diploma education programs, bachelor, master, specialist, and doctoral degrees (Act No. 20 of 2003 concerning the National Education System).

Ethnicity is the grouping of people based on cultural similarity [15]. The research conducted by Pratiwi \& Prijati [7] stated that Spanish students are more willing to take risks in financial management than American students, which means that Spanish students can be more willing to take risks. This proves that ethnicity has an influence on investor behavior in investing. Perry and Morris [10] also explained that financial behavior can be influenced by race, ethnic background, and locus of control. This is 
seen in black and Latin American ethnicities in studies that show how these ethnicitiers have more responsible financial behavior compared to white and Asian ethnicities.

Investment is an activity of placing funds on an asset or more during a certain period in the hope of obtaining profits [1]. According to Gunawan et al., [16] and Ariadi et al., [1], investment is divided into 2 types, investment in real assets and investment in financial assets. Real asset investment is a form of investment in assets that are physical or tangible such as land, buildings (property), machinery, gold, and others. On the other hand, investment in financial assets is a form of investment in financial concepts, such as deposits, shares, mutual funds, bonds, warrants, and others. Investment decisions themselves are defined as individual decisions in placing a number of funds on certain types of investments [17]. When investing, individuals can allocate assets by diversifying risks in order to reduce investment risks so as to provide returns in line with investor expectations.

Based on the objectives of the research and the study of the theory discussed, the hypotheses in this study are:

$\mathrm{H}_{1}$ : The level of financial literacy influences employee investment decisions.

$\mathrm{H}_{2}$ : Gender influences employee investment decisions.

$\mathrm{H}_{3}$ : Education influences employee investment decisions.

$\mathrm{H}_{4}$ : Ethnicity influences employee investment decisions.

\section{Research Method}

The population in this study are employees and researchers, selected using the purposive sampling method. The research variables used in this study include the independent variables financial literacy, gender, education, and ethnicity, accompanied by the dependent variable investment decisions. The following describes the operational definitions and measurement variables.

Financial literacy is defined as knowledge to manage finances [18] as supported by Artina \& Cholid [17]. Financial literacy is also interpreted as the financial abilities and knowledge a person has in order to be able to make financial decisions that aim to improve living standards and achieve prosperity. In this variable, there are four aspects that become a benchmark for a person to have financial literacy, namely:

1. Basic Financial Knowledge, which includes knowledge of interest rates, inflation, currency exchange rates, knowledge of formal financial products, knowledge of liquidation and assets, and knowledge of general personal finance, 
2. Saving and Borrowing, which includes knowledge on savings and loans,

3. Insurance, which includes insurance-related knowledge, and

4. Investment, which includes knowledge of market interest, stocks, bonds, mutual funds and investment risks.

The measurement of financial literacy variables is done using a ratio scale by dividing the number of correct answers with the total number of questions given to respondents.

\subsection{Gender}

Gender is the biological and physiological difference between a person from birth [1]. Gender variables in this study were measured using a nominal scale.

\subsection{Education}

Education is defined as the level of mastery of knowledge possessed by a person and manifested through his ability to understand things well [14]. Formal education is defined as structured and tiered education consisting of basic education, secondary education, and higher education (Law No. 20 of 2003 concerning the National Education System). Education variables in this study were measured using an ordinal scale.

\subsection{Ethnicity}

Ethnicity is a grouping of people based on cultural equality [1]. In this study, the ethnicity to be examined is the variety of ethnic groups scattered in Surabaya, especially Balinese, Batak, Javanese, Madurese, Sundanese, Chinese, and other ethnic groups, measured using a nominal scale.

\subsection{Investment Decisions}

Investment decisions are defined as the decision of an individual to put a number of funds on certain types of investments [17]. Assessment of investment decisions can be appraised through the ownership of instruments or investment products owned by respondents. A ratio scale is used in this study to determine the amount investment 
instruments owned by adding up the ownership percentage of real assets and financial assets of respondents.

$$
\text { Investment Decisions }=\frac{\text { Real Asset Percentage }}{\text { Financial Asset Percentage }}
$$

\subsection{Methods of Data Analysis}

This study uses a multiple linear regression research model that aims to determine the effect or relationship linearly between two or more independent variables with one dependent variable. Data analysis is done using a multiple linear equation model as follows:

$$
Y=\alpha+\beta_{1} X_{1}+\beta_{2} X_{2}+\beta_{3} X_{3}+\beta_{4} X_{4}+e
$$

Legend:

Y: Investment Decisions

$\alpha$ : Constant

$\beta_{1}$ : Financial literacy regression coefficient

$\mathrm{X}_{1}$ : Financial Literacy

$\beta_{1}$ : Financial literacy regression coefficient

$\mathrm{X}_{2}$ : Gender

$\beta_{1}$ : Educational regression coefficient

$\mathrm{X}_{3}$ : Education

$\beta_{1}$ : Ethnic regression coefficient

$\mathrm{X}_{4}$ : Ethnicity

e: error standard

\section{Results}

Respondents in this study are employees who have invested in both real assets and financial assets. The researcher distributed questionnaires to 210 employees and received 159 questionnaires. Of the 159 , questionnaires that fit the research criteria and can be processed are only 100 questionnaires. The remaining questionnaires cannot be processed due to reasons that is not in accordance with the criteria of the study such as the respondents had not invested before, the questionnaire returned empty, and there are an incomplete answers from the respondents. 


\subsection{Charasteristics of Respondents}

Descriptive analysis is used to describe the identity of respondents and the variables in this study, namely financial literacy, gender, education, ethnicity, and investment decisions. In this study, most respondents are female. Of the 100 data processed, as many as $54 \%$ or 54 people are females. The largest proportion of respondents have undergraduate or postgraduate education, while the smallest proportion are Diploma / D3 educated. In the ethnicity section, it can be explained that as many as 5\% of the total respondents are Batak, 38\% are Javanese, $49 \%$ are Chinese, and $8 \%$ are from other ethnic groups such as Manado, Ambonese, Timorese, and Dayaks. This shows that respondents in this study are mostly of the Chinese ethnicity.

In the investment decision section, as many as 55\% of respondents chose to invest in financial assets such as deposits, bonds, stocks, and mutual funds. This shows that respondents in this study tend to invest in financial assets. Then regarding the term of investment, respondents of this study mostly have invested for quite a long time, around 1-3 years or more than 3 years.

\subsection{Financial Literacy and Types of Investment}

This study found that respondents with low and medium financial literacy levels tend to choose to invest in financial assets, while respondents with high financial literacy levels tend to invest in both types of investment (real and financial assets). So, it can be said that respondents with high levels of financial literacy prefer to invest in several investment products (asset diversification). Both male and female employees tend to invest in financial assets, especially deposits. Employees with S1, S2 and S3 educations tend to invest in financial assets, especially deposits. This study shows that ethnicity in this study, which are Batak, Javanese, Chinese, and other ethnic groups have a similarity, which is the tendency to invest in financial assets, especially deposits.

\subsection{Normality Test}

The normality test that has been done shows the results of the normality test with a significance of $0.55>0.05$. So, it can be concluded that the data in this research is normally distributed. Multicollinearity test showed that the results have a tolerance value of $>0.1$ and VIF value of $<10$. So, it can be concluded that there were no symptoms of multicollinearity in the regression. The heterocedasticity test showed that the value of 
sig. on variables $X 1, X 2, X 3$, and $X 4$ are $>0.05$, indicating the absence of symptoms for heteroscedasticity in the data of the study.

\subsection{Double Linear Regression Analysis}

The result of the regression model is:

$$
Y=0.307 X_{1}+0.071 X_{2}+0.091 X_{3}+0.157 X_{4}
$$

\subsection{F-test, t-test, and R-test}

The F-test shows a significance of $0.016<0.05$. This shows that the variables of financial literacy $(X 1)$, gender $(X 2)$, education (X3), and ethnicity (X4) are feasible in the multiple regression equation model. For the t-test, the significance value of the financial literacy variable is $0.002<0.05$ and the gender, education, and ethnic variables are of significance $>0.05$. This shows that only the financial literacy variable (X1) has a partial significant effect on the dependent variable, namely the investment decision $(Y)$ of the employee. While for the correlation coefficient, the $\mathrm{R}$ value is 0.346 or $34.6 \%$. This shows that there is a weak linear relationship between financial literacy variables ( $\mathrm{X} 1)$, gender (X2), education (X3), and ethnicity (X4) on investment decisions (Y). Then the resulting coefficient of determination is 0.083 or $8.3 \%$. This shows that $8.3 \%$ of employee investment decisions can be explained by variables financial literacy, gender, education, and ethnicity, while the remaining $92.7 \%$ is explained by other factors not examined in this study.

\section{Discussion}

\subsection{Effect of the Level of Financial Literacy on Employee Invest- ment Decisions}

The results of the t-test value of the financial literacy level on investment decisions has a significance value of $0.002<0.05$. Therefore, it can be concluded that the level of financial literacy has a significant positive effect on employee investment decisions. Hence, the $\mathrm{H} 1$ hypothesis which states that the level of financial literacy influences investment decisions is acceptable.

These results support a previous research conducted by Putri \& Rahyuda [5] which stated that financial literacy is influential in determining the behavior of individual 
investment decisions. Likewise, the study of Artina \& Cholid [17] stated that there is an influence of financial literacy on individual investment decisions. This is also in accordance with the statement of Margaretha \& Pambudhi [13] that financial literacy is very important for individuals, so they do not make mistaken determination of their financial decisions. A good level of financial literacy can help individuals determine their financial decisions on financial products optimally. Lack of financial knowledge can make it difficult for individuals to invest or access financial markets.

The role of financial literacy can be seen from research respondents with high financial literacy who tend to choose to invest in various investment products, which are both investment in real and financial assets. This shows that respondents already have the awareness to allocate assets in investing. Asset allocation that is carried out served to divide the assets held into several different types of investments with the aim of reducing risks in investing, as supported by Gunawan [16].

\subsection{Effect of Gender on Employee Investment Decisions}

The result of the t-test value for gender on investment decisions has a significance of $0.476>0.05$. So, it can be concluded that there is no significant influence by the variable of gender on individual investment decisions. In this study, both men and women tend to choose to invest in financial assets rather than investing exclusively in real assets or investing in both types of assets. So that it can be said that both male and female employees have the same consideration in making investment decisions. Therefore, the $\mathrm{H} 2$ hypothesis which states that gender influences investment decisions is not acceptable.

The result of the study is not in accordance with the research conducted by Pak \& Mahmood [8] and Putri \& Rahyuda [5] which stated that there is a gender influence on the behavior of individual investment decisions which can be seen through differences in investment behavior between men and women. However, the results of this study are supported by a research by Pratiwi \& Prijati [7] which stated that there is no gender influence on the type of investment chosen and the behavior of Surabaya capital market investors. The researcher interpreted that there was no influence between gender variables on investment decisions because respondents in the study had a tendency to avoid risk. This can be seen from the form of investment held by respondents in the study who tend to invest in financial assets, especially deposits as a form of general investment and is easily accessible to the public. This makes both male and female 
investors in the study to have the same consideration in making financial decisions as can be seen from the tendency to choose financial assets.

\subsection{Educational Influence on Employee Investment Decisions}

Test results show the value of the education t-test on investment decisions with a significance of $0.360>0.05$. So, it can be concluded that there is no significant influence of educational variables towards employee investment decisions. In this study, respondents with the last level of education of bachelor (S1), master (S2), and doctorate (S3) tend to invest in financial assets. So that it can be said that employees with a level of education of S1, S2, and S3 have the same consideration in investment decisions. Therefore, the $\mathrm{H} 3$ hypothesis which states that education influences investment decisions is not accepted.

The results of this study are not in accordance with the research conducted by Artina \& Cholid [17] which stated that there is an educational influence on individual investment decisions. The higher the level of education achieved, the more knowledge they have so that individuals will be more careful in making financial decisions. Pratiwi \& Prijati [17] also stated that the higher the education, the higher the individual's tolerance for risk. However, these results are supported by the results of the research conducted by Pratiwi \& Prijati [17] which proved that there is no influence of education on the type of investment and behavior of Surabaya capital market investors. The researcher interpreted that there was no influence of education on investment decisions because $52 \%$ of respondents in the study were employees with S2 Education which, showed in this study the same consideration in making investment decisions, namely investing in financial assets. In addition, there are other factors such as easy access to information related to financial knowledge (for example, through offers from the bank, investment activity facilities provided) so that respondents with a level of education other than S2 can easily obtain the same information and making financial decisions that are quite similar.

\subsection{Ethnic Influence on Employee Investment Decisions}

The results of value testing of the ethnic t-test on investment decisions has a significance of $0.115>0.05$. So, it can be concluded that there is no significant influence between ethnic variables on employee investment decisions. The previous section shows that employees from the Batak ethnicity have the same tendency to invest in financial assets 
and both types of assets (real and financial assets). Meanwhile, employees from the Javanese and TiongHwa ethnic groups both tend to invest in financial assets. The absence of this difference can be caused by the similarity of ethnic characteristics in this study, which tends to have the same consideration in making investment decisions. Therefore, the $\mathrm{H} 4$ hypothesis which states that ethnicity influences investment decisions is not accepted.

These results are not in accordance with the research conducted by Agyemang \& Ansong [19] which showed that Ghana investors prioritize family comfort and safety as the main factors in investment decision making and the research of Albaity \& Rahman [11] which stated that there are characteristic differences between Malaysian and Chinese Malaysians in choosing risky investments. However, these results are supported by a research conducted by Ariani et al. [11] which proved that there is no ethnic influence on individual investment decision making.

The researcher interpreted the absence of ethnic influence in this study is due to the fact that ethnicities in the study, although consisting of various different ethnicities, all have characteristics of the Surabaya community, which tends to be collectivism. The collective nature of mutual cooperation has an impact on the tendency of people to be more careful in making financial decisions [1]. This causes financial decisions made to tend to be in the form of low-risk investments, namely in financial assets, and especially deposits.

\section{Conclusion and Suggestions}

\subsection{Conclusion}

Based on the results of testing and data analysis that has been done, it can be concluded that the level of financial literacy has a significant effect on employee investment decisions, gender does not have a significant effect on employee investment decisions, education has no significant effect on employee investment decisions, and ethnicity has no significant effect on employee investment decisions.

\subsection{Research Limitations}

In this study, many questionnaires were returned empty and with incomplete answers and only with a limited time for respondents to answer the questionnaires. So, the data obtained is less than the expectations of researchers and not in accordance 
with the initial target specified. The questions in the questionnaire were less adjusted and clarified so many respondents did not understand the intent of the question and caused the dubious quality of the responses. In addition, respondents in this study were respondents with a high level of education, namely respondents with undergraduate education (S1 and S2). Therefore, there are a lot of specific considerations regarding answering the questionnaire.

\subsection{Suggestions}

The researcher suggests for further research to add other variables that did not exist in this study with the addition of other demographic factors such as age, income, marital status, and other demographic factors as well as psychological factors such as locus of control, risk tolerance, and overconfidence which also allegedly influence investment decisions. Then the questions related to the level of financial literacy used in the questionnaire of further researches can also be modified with a more general and easyto-understand language in order to facilitate respondents in answering. Respondents in the next study can be expanded to investors from certain cities or regions to better describe investment decisions in a broader scope. Further researches can also examine forms of investments that have significant difference in terms of risk, such as difference in investments like deposits and shares.

\section{References}

[1] Ariadi, R., Malelak, M. I., Astuti, D. (2015). Analisa Hubungan Financial Literacy dan Demografi dengan Investasi, Saving, dan Konsumsi. Jurnal Finesta, 3(1), 7-12.

[2] Pritazahara, R., \& Sriwidodo, U. (2015). Pengaruh Pengetahuan Keuangan dan Pengalaman Keuangan terhadap Perilaku Perencanaan Investasi dengan Self Control sebagai Variabel Moderating. Jurnal Ekonomi dan Kewirausahaan, 50(1), 28-37.

[3] Putra, I. P. S., Ananingtiyas, H., Sari, D. R., Dewi, A. S., Silvy, M. (2015). Pengaruh Tingkat Literasi Keuangan, Experienced Regret, dan Risk Tolerance pada Pemilihan Jenis Investasi. Jurnal of Business and Banking, 5(2), 271-282.

[4] Fahmi, I. (2014). Studi Kelayakan Bisnis dan Keputusan Investasi. Jakarta: Mitra Wacana Media.

[5] Putri, N. M. D. R., Rahyuda, H. (2017). Pengaruh Tingkat Financial Literacy dan Faktor Sosiodemografi terhadap Perilaku Keputusan Investasi Individu. E-Journal Ekonomi 
dan Bisnis Universitas Udayana 6(9), 3407-3434.

[6] Budiarto, A., Susanti (2017). Pengaruh Financial Literacy, Overconfidence, Regret Aversion Bias, dan Risk Tolerance terhadap Keputusan Investasi. Jurnal IImu Manajemen, 5(2), 1-9.

[7] Pratiwi, I., \& Prijati. (2015). Pengaruh Faktor Demografi terhadap Jenis Investasi dan Perilaku Investor Pasar Modal Surabaya. Jurnal Ilmu dan Riset Manajemen, 4(2), 1-15.

[8] Pak, O., Mahmood, M. (2015). Impact of Personality on Risk Tolerance and Investment Decisions (A Study on Potential Investors of Kazakhstan). International Journal of Commerce and Management, 25(4), 370-384.

[9] Chavali, K., \& Mohanraj, M. P. (2016). Impact of Demographic Variables and Risk Tolerance on Investment Decisions: An Empirical Analysis. International Journal of Economics and Financial Issues, 6(1), 169-175.

[10] Perry, V. G., \& Morris, M. D. (2005). 'Who is in Control? The Role of Self-perception, Knowledge, and Income in Explaining Consumer Financial Behavior'. Journal of Consumer Affairs, 39(2), 299 -- 313.

[11] Albaity, M. P. \& Rahman, M. (2012). Gender, Ethnicity, and Religion and Investment Decisions: Malaysian Evidence. Journal of Sociological Research, 3(2), 502-519.

[12] Yushita, A. N. (2017). Pentingnya Literasi Keuangan bagi Pengelolaan Keuangan Pribadi. Jurnal Nominal, 6(1), 11-26.

[13] Margaretha, F., \& Pambudhi, R. A. (2015). Tingkat Literasi Keuangan pada Mahasiswa S-1 Fakultas Ekonomi. Jurnal Manajemen dan Kewirausahaan, 17(1), 76-85.

[14] Iswantoro, C., \& Anastasia, N. (2013). Hubungan Demografi, Anggota Keluarga dan Situasi dalam Pengambilan Keputusan Pendanaan Pembelian Rumah Tinggal Surabaya. Jurnal Finesta, 1(2), 124-129.

[15] S., Rahmah, P. A., Putri, Y. R., Rohmah, M., Budiningrum, A., \& Lutfi. (2015). Pengaruh Literasi Keuangan, Locus of Control, dan Etnis terhadap Pengambilan Keputusan Investasi. Jurnal of Business and Banking, 5(2), 257-270.

[16] Gunawan, M. F., Linawati, N., Memarista, G. (2015). Pengaruh Risk Tolerance dan Personality Traits terhadap Pemilihan Portofolio Investor di Surabaya. Finesta, 3(2), 33-37

[17] Artina, N., Cholid, I. (2018). Pengaruh Tingkat Literasi Keuangan dan Faktor Demografi terhadap Pengambilan Keputusan Investasi (Studi Kasus Pegawai Kantor Badan Kepegawaian Daerah Sumatera Selatan). Jurnal Keuangan dan Bisnis, 84-99.

[18] Chen, H. \& Volpe, R. P. 1998. An Analysis of Personal Financial Literacy Among College Students. Financial Services Review, 7(2), 107-128. 
[19] Agyemang, O. S., \& Ansong, A. (2016). Role of Personal Values in Investment Decisions: Perspectives of Individual Ghanaian Shareholders. Management Research Review, 39(8), 940-964. 